\title{
DỨBin
}

Technological University Dublin

ARROW@TU Dublin

\section{Emerging Threats for MNC Subsidiaries and the Cycle of Decline}

\author{
Pamela Sharkey Scott \\ Technological University Dublin, pamela.sharkeyscott@tudublin.ie \\ P. T. Gibbons Prof \\ University College Dublin, pat.gibbons@ucd.ie
}

Follow this and additional works at: https://arrow.tudublin.ie/buschmanart

Part of the International Business Commons

\section{Recommended Citation}

Pamela Scott, Patrick T. Gibbons, (2011) "Emerging threats for MNC subsidiaries and the cycle of decline", Journal of Business Strategy, Vol. 32 Iss: 1, pp.34 - 41

This Article is brought to you for free and open access by the School of Management at ARROW@TU Dublin. It has been accepted for inclusion in Articles by an authorized administrator of ARROW@TU Dublin. For more information, please contact arrow.admin@tudublin.ie, aisling.coyne@tudublin.ie, gerard.connolly@tudublin.ie.

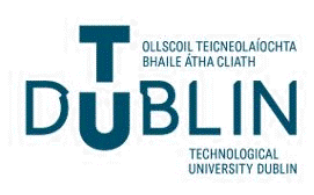


One of the primary threats evidenced in both the academic and practitioner press is the potential for multinational corporations (MNC) to shift their domestic and foreign subsidiary operations to low cost locations, including China, India and the Eastern Bloc. We argue that as a result of the emphasis on cost driven relocation risk, managers have largely overlooked increasing pressures from other areas. We demonstrate how these threats potentially create a virtual circle of decline as they combine to undermine the ability of unit managers to achieve the knowledge sharing and strategic perspective required to add value. While our study focused on subsidiary units of MNCs these threats have similar implications for divisions and departments of all large organisations. Identifying these emerging dangers enables unit management to more effectively and pro-actively respond to minimise the possible negative impact on their operations.

We recently completed an extensive literature search, a series of interviews with directors of major subsidiaries, and a survey targeted at the total population of Irish subsidiaries (see Box 1, How the Research was Conducted) to identify the emerging pressures in subsidiaries of large organisations operating in today's dynamic business environment. As a research site, Ireland's history of attracting high levels of Foreign Direct Investment from MNCs, combined with its vulnerable location on the periphery of Europe, renders it particularly suitable for indentifying shifts in organisational behaviour. Through integrating the key findings from this multifaceted exploration, we discovered that, aside from ongoing cost driven relocation, three new distinct platforms of threats are emerging:

- Erosion of Geographic and Trade Barriers. More of the world is now accessible to trade, which provides organisations with access to new markets and to cheaper inputs, including similarly skilled labour (Mudambi, 2008). The former EU Accession countries now offer a pool of skilled and ambitious workers often available at a tenth of comparable Western prices within a similar infrastructure. Free and reciprocal trade agreements and active promotion of inter-regional trade is increasingly supported. In particular the inclusion of China into NATO provides access to its burgeoning consumer market but Western organisations are only beginning to appreciate that reciprocal free trade means reciprocal competition in their home countries.

- Complex Corporate Governance and Compliance Issues. Large corporations are increasingly vulnerable to any failure of their dispersed units to comply with increasingly rigorous and intricate corporate governance requirements. This has led some formerly federal type organisations to re-evaluate the risks of their decentralised strategy. For example, the failure of its Eastern Bloc operation to meet compliance regulations led to the imposition of financial penalties and negative publicity for a major international building corporation. This prompted centralisation of more decision making in headquarters. CHECK CAN USE

- Increasing sophistication and declining costs of ICT systems. ICT is applauded for its multiple benefits in terms of promoting inter and intra organisational collaboration, and enabling continually improving products to be delivered faster and cheaper. In particular, for large organisations ICT enables greater integration and communication with both sister operations and headquarters, enhancing information sourcing, sharing and access to opportunities in multiple locations. However, the potentially negative implications of technological driven developments are often underplayed, sometimes to reduce resistance to their introduction.

From our discussions with senior management we are convinced of the need to highlight how these threats have significant implications for large organisations, and particularly subsidiary units of MNCs. The potential direct implications of these challenges are presented here as distinct and separately identifiable for clarity, but in reality the outcomes collectively reinforce the emerging 
threats and drive further changes themselves. For example, the breaking down of value chains into distinct activities facilitated by more sophisticated ICT systems and the erosion of trade barriers is both a result and a driver of further change within the organisation as it blurs subsidiary boundaries and erodes the subsidiary as a distinct entity. While acknowledging the overlapping influences of the challenges and their effects, we categorise the implications in terms of increasing headquarters monitoring and control and disaggregating value chains, and discuss their implications for the ability of business units to compete.

\section{Increasing Headquarters Monitoring and Control}

Over the last two decades headquarters has increasingly granted greater freedom to its operations to benefit from the local learning of its independent subsidiaries, access to local resources and competencies to achieve learning and dynamism throughout the MNC (Anderson et al, 2009). Many national subsidiaries are like 'miniature replicas' (Young et al, 1988) of their parent and encompass a range of value chain activities to serve their local and nearby markets. However, increasingly sophisticated and relatively cheap ICT facilitate greater monitoring and control. It is argued that this has the benefit of reducing agency costs, or the risk of unit managers acting in their own or the subsidiary's interest rather than in the best interests of the overall organisational, but we argue that there is potentially a high price to be paid in terms of stifling the potential for unit contribution. Our research indicates the following implications:

Exposure of Subsidiary Networks: One of the benefits of the 'miniature replica' form of subsidiary is that its breath of activities encourages the subsidiary to engage in network building within the local environment as well as with its sister subsidiaries. This increases the subsidiary's access to local knowledge and opportunities. Subsidiary external networks embrace local institutions such as universities and government agencies, as well as suppliers and competitors (Lee et al, 2001). Headquarters increased ability to access subsidiary information systems now allows it to monitor its 'live' contacts, and increases its knowledge of subsidiary activities and contacts. This effectively reduces the exclusivity of the subsidiary's contacts, and significantly enhances headquarters' ability to be involved in key subsidiary network relationships, and to control and co-ordinate these relationships from a distance. This ultimately enables any potential takeover of subsidiary relationships by headquarters, reducing the subsidiary's ability to build a strong position for itself within a particular location.

Limited Potential for Distinctiveness: Increasing international visibility requires organisations to ensure their dispersed activities comply with both local and international regulatory and competition rules. This encourages standardisation of internal routines and procedures. However, greater standardisation reduces flexibility and makes it more difficult for subsidiaries to achieve distinctiveness within the organisation. Subsidiary management aim to make their subsidiary distinctive from the headquarters perspective, as this is pivotal to their developing a more prominent role within the MNC. It also provides a platform for them to engage with headquarters and influence how the strategy for their subsidiary, if not the broader MNC, will be developed. Without distinctiveness to achieve headquarters recognition, subsidiary activities are more likely to be perceived on a purely cost / contribution basis. This has an increasingly negative effect as the less distinctive a unit becomes the less likely it is to be perceived as adding value to the organisation.

Reduced Subsidiary Discretion: Having the ability to frequently monitor subsidiary activities in itself encourages tighter control. It can be expected that increased monitoring will reduce the subsidiary's ability to act in response to local opportunities in two ways. Firstly, it will reduce subsidiary autonomy or the unit's freedom to act in response to opportunity without first obtaining headquarters' permission. Studies to date have connected autonomy with initiative generation(Birkinshaw et al, 1998) indicating that any reduction in a subsidiary's ability to make 
decisions at a local level will negatively impact its potential to contribute to the MNC. The local autonomy offered by a federally structured organisation supports the access to knowledge and generation of initiatives by the subsidiary which can then be transferred across the MNC to create competitive advantage. Secondly, increased monitoring by headquarters will reduce the level of slack or unused available resources in the subsidiary system. Both anecdotal evidence and empirical studies (for example, Nohria and Gulati, 1996) support the role of slack resources in generating subsidiary initiatives. The combination of reduced autonomy and reduced slack means that both the subsidiary's ability to make decisions and its resources to execute them. This has potentially critical implications for subsidiary contribution. For example, units will no longer be able to decide if it is worth road testing a particular idea with some preliminary market research, and then finance this new testing to assess new product viability. Innovation is challenging anyway but within a restricted and watchful organisation it will be even more difficult to achieve.

\section{Disaggregating Value Chains}

It must be acknowledged that ICT has many positive benefits including the elimination of redundancy and duplication of effort, but it also has wider potentially negative implications. However, one of the negative impacts, from a subsidiary perspective, is that increasing ICT sophistication has transformed headquarters' ability to orchestrate its value chain activities, both within the organisation and with other firms (Buckley, 2009). ICT increasingly connects end - to - end products globally within and across organisations, allowing firms in separate value chains to communicate and co-ordinate their activities. The effectively reduces the risk of slicing value chain activities into separate and often unrelated strands across organisational units. Following our research, we expect this to have the following impact within large organisations:

Transactional attitude to Subsidiary Strategy. Breaking the value chain down into strands of activities enables packages of activities to be assessed and priced facilitating their relocation to the lowest cost producer, either inside or outside the organisation (Buckley, 2009; Mudambi, 2008). Information and virtual products can be transported seamlessly from almost anywhere, facilitating the shifting of manufacturing and increasingly R\&D to geographically distant locations.

Infrastructural improvements in many of the 'new' markets including China and India facilitate their bids to win more value added activities, further undermining the competitive advantage of Western based units. More worryingly, this fragmentation of organisational activities encourages headquarters to adopt a short term, transaction based perspective rather than to focus on the long term strategy for that subsidiary. One unit director bemoaned that 'we need a vision for our future, not another spread sheet!'

Erosion of Synergy Potential. The potential for recognising synergies within the location is significantly reduced as the different activities are likely to operate independently of each other and with different reporting structures. Even where there are areas of overlap the management costs of liaising may be prohibitive. While headquarters may have the 'big picture' and understand the contribution of the different units this will be blurred at the ground level, reducing the potential to achieve synergies from the various areas. In addition, non routine problems experienced by different units engaged in similar but disjoint activities, even potentially within the same unit, may not benefit from internal communication as each separately engages in problem solving. Information is often not valuable in isolation and needs the insights provided by awareness of the bigger picture. Without an overall picture of how the subsidiary's activities relate to the wider organisation units only have separate pieces of a jigsaw, no box!

Control and Command HQs. As mentioned earlier, the emergence of the federal view of the MNC recognises the potential of the diverse units within the MNCs to contribute to its competitive advantage through knowledge sharing and opportunity identification in its dispersed operations 
(Anderson et al, 2001). This implies that subsidiary operations have the strategic perspective and the autonomy to recognise opportunities and generate initiatives in response (Birkinshaw, 1998). Often these initiatives are generated without the parent's consent or even knowledge as it is often easier to be forgiven afterwards than achieve permission in advance. For example, Baileys Irish Cream was developed by the Irish subsidiary of the International Distillers and Vitners Group Irish Distillers Group, then owned by Grand Met to use locally based product (cream) which would embed the subsidiary in its location (Delaney,2001). The parent dilemma within this approach to subsidiary management is how best to communicate and co-ordinate activities to leverage the local knowledge and innovative capacities of subsidiaries (Ghoshal and Bartlett, 1998). Tight control by headquarters restrains the MNC from 'realizing the many well documented benefits of strategically independent subsidiaries .....learning from local systems of innovation, using and integrating local resources and competencies, and generally introducing a heightened level of dynamism into the parents's MNC (Mudambi and Navarra, 2004, pp. 387). Our interviews with subsidiary CEOs indicate that disaggregating value chains into separate strands is shifting this perspective to a more active controlling and commanding role. This has negative impact on the potential for the MNC to learn and benefit from its subsidiary network as we will now discuss.

\section{Virtual Circle of Decline}

Headquarters' enhanced ability to relocate strands of activities from across the value chain and across nations means that what constitutes a subsidiary within a particular location is likely to be much less structured and more blurred. Strands of activities do not have the same cohesiveness and structure as the 'national subsidiary'. For example, the Irish operation of a particular MNC constituted 17 different activities, many integrated with separate value chains with different matrix reporting structures. The breakdown of subsidiary businesses into combinations of possibly randomly assigned value chain activities, closely monitored and with little autonomy substantially reduces its ability to adopt a strategic perspective and to identify how its operation fits within the organisation. This reduces the potential for subsidiary initiative as its role will be limited to achieving its value chain activities efficiently and effectively. This in turn increases the likelihood that allocation of future investments will be on a cost basis only and the potential for the subsidiary to engage in strategically significant activities will be further undermined. We propose that these factors will combine to lead to a virtual circle of decline.

While it is almost impossible to select a position as a starting point to discuss the virtual circle of decline we begin at the erosion of the subsidiary's ability to develop those combinative capabilities, the foundation of its ability to contribute to the MNC.

\section{Combinative Capabilities.}

Formerly national subsidiaries where the MNC located all of the activities associated with a particular value chain within each country and which acted as distinct strategic entities may now house unrelated activities of not just one, but of several of their organisation's value chains attached to different divisions and departments.

The MNC exists to exploit synergies between its subsidiary units. Knowledge may have little value in isolation but when combined within a framework the subsidiary can understand how it relates to other organisational activities, and how they relate to each other. The subsidiary's combinative capabilities enable the subsidiary to use its locally based knowledge and opportunities to generate initiatives for exploitation across the organisation. Slicing activities and related knowledge into randomly unconnected pieces slivers reduces the ability of management at both the subsidiary and at headquarters level to achieve locational synergies. 
One of the benefits is access to local knowledge from clusters and also within the subsidiary. Now within the subsidiary they will be operating on different parts of the supply chain. While this offers some opportunities in terms of cross fertilisation of ideas and adapting solution templates from different contexts, its downside includes that they may be effectively talking a different language, and in the absence of a strong culture that they will not be motivated to communicate and cross fertilise.

If as Kogut and Zander (1992) argue, individuals recombine their current skills by transferring information across the organisation's social network then, we proposes that rather like criminal cell structures minimising risk of leaking information, dispersed strands of value chains will lead to corals of disjoint information. This will ultimately inhibit the subsidiary ability to identify and build the combinative competencies it needs to build to generate initiatives.

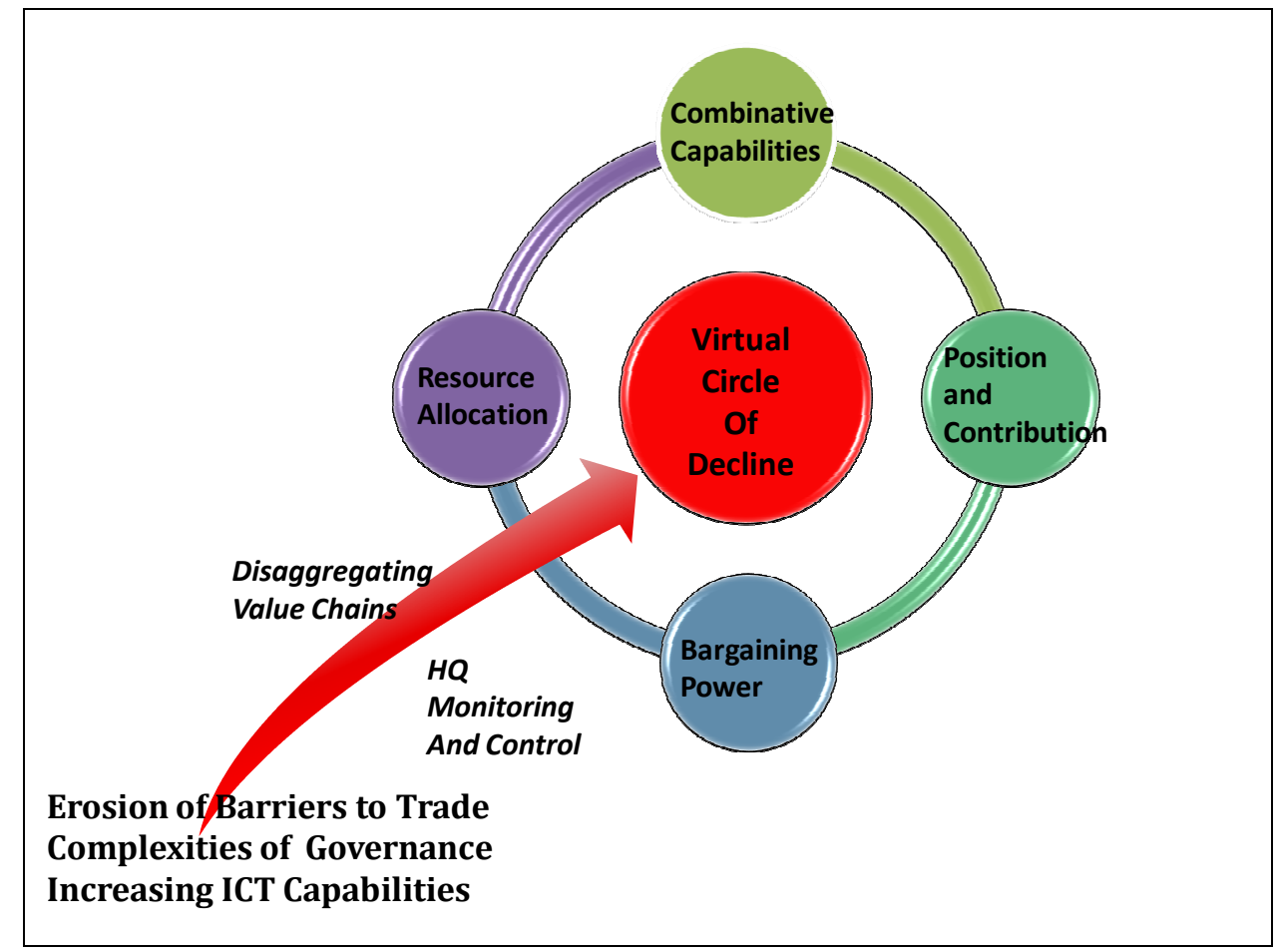

Position and Contribution. A subsidiary's position within the MNC will depend on its encompassing capabilities which are valuable to the MNC and the contribution which flows from them. If as we argue the subsidiary's combinative capabilities will be reduced as a result of this shift in organisational structure, then it is likely to be weakened in terms of the contribution it can make to the organisation.

Reduction of Unit Bargaining Power. A subsidiary's bargaining power arises from intra MNC knowledge flows and its position within the MNC (Mudambi and Navarra, 2004). The erosion of the federal organisation structure which supports subsidiary autonomy and knowledge seeking, combined with the decline in the subsidiary's combinative capabilities and its lack of visibility within the organisation due to decline in its contribution, will reduce the unit's bargaining power with headquarters.

The ability to package activities and effectively force subsidiaries and external competitors to bid for them provides headquarters with a wider range of options in terms of its location of routine operations and reduces its reliance on specific units within its organisation. These units would normally have used that reliance to build bargaining power (Mudambi and Navarra, 2004) and 
reduced relocation risk by negotiating resources from headquarters to build next generation competencies. This exacerbates the virtual circle of decline, as without the resources today to position for the challenges of tomorrow their activities will slip further down the value chain.

Conclusion

Restrictions on the ability of subsidiaries to develop a unique position to ensure their survival and growth are increasing due to increasing globalisation of systems and processes. This study evidences the broad threats from multiple sources which threaten MNC operations, particularly in developed regions. It also demonstrates how these threats create a virtual circle of decline as they constantly undermine the ability of subsidiary management to encourage their units to behave in a manner which would improve their contribution, leading to self fulfilling cycles of erosion. Management are extremely conscious of the need to promote their subsidiary's position within the MNC and to position for further reinvestment. This leads to a bigger argument of whether the MNC perceives its role as a supply chain / logistics orchestrator neural centre with ganglia central logistics centre weaving the strands of the multiple value chains. In this case only the pricing of transaction costs support the argument for ownership, and there is no need for autonomy, entrepreneurship and strategy development as they would merely distract from the operational function of the unit. This it could be argued would lead eventually to only cost leadership positions. If, on the other hand, as Kogut and Zander (1992) argue firms exist because they are better at sharing and transferring knowledge and learning new skills internally than by dealing with the market, then headquarters is the leader of a federation of quasi independent units each potentially accessing knowledge and generating innovations for diffusion across the MNC and is a source of differentiation and sustainable competitive advantage. Any shift to a 'global factory' (Buckley, 2009) then has damaging implications for the future of the multinational organisation.

We hope we have provided some useful insights.

\section{Exhibit 1.}

\section{Box 1 - How the Research was Conducted}

In response to the needs of both practitioners and policy makers, Dublin Institute of Technology and University College Dublin jointly undertook a major review of senior management practices in Irish subsidiaries of foreign MNCs. Designed to combine capturing the rich insights of practitioners with achieving the required generalisability of findings, the study incorporated both a survey of the total population of Irish subsidiaries $(\mathrm{c} 1,100)$ and an interview programme of subsidiary CEOs and senior executives. The survey achieved a strong response rate of $24 \%$ largely from CEO's / General Managers (88\%), and the respondent profiles confirmed that both a diversified country of MNC origin (US 41\%, UK 16\%, Other EU 31\%), and range of industries, including pharmaceutical (9\%) and ICT (21\%) are represented. The objective of the survey was to capture variations in subsidiary autonomy, entrepreneurship, strategy development processes, networks, initiative generation, international responsibility, performance and the role of the subsidiary CEO.

The interview programme comprised a series of in-depth interviews with CEOs and their top management executives in 8 subsidiaries, selected to provide diversity in terms of both industry and geographical origin of the parent operation. The interviews provided insights into the real experiences behind the survey data, and described the constant fight for survival and growth in the face of increasing relocation risk. While both the survey and interview programme were set in a particular geographic location, the results are generalisable to any MNC subsidiary and offer unique insights into their increasingly complex internal and external operating environments. 
INCREASING EMPHASIS ON COST RESULTS IN A FOCUS ON EXPLOITATION RATHER THAN

EXPLORATION NOT JUST FOR SUB BUT FOR WHOLE MNC and where will it generate the iniitative to be part of the next generation of products.

\section{Bibliography}

Andersson, U., Forsgren, M., Holm., U., 2007. Balancing subsidiary influence in the Federative MNC: A business network view, Journal of International Business Studies 38, 802-818.

Birkinshaw, J., Hood, N., Jonsson, S.,1998. Building Firm-Specific Advantages in Multinational Corporations: The role of Subsidiary Initiative, Strategic Management Journal 19, 221-241.

Buckley, P. J., 2009. Internalisation thinking: From the multinational enterprise to the global factory. International Business Review 18, 224-235.

Cantwell, J., Mudambi, R., 2005. MNE Competence-Creating Subsidiary Mandates, Strategic Management Journal 26, 1109-1128.

Kogut, B., Zander, U., 1992Knowledge of the Firm, Combinative Capabilities, and the Replication of Technology, by Bruce Kogut and Udo Zander, Organization Science, 3(3), 383-397.

Lee, C., Lee, K., Pennings, J.,2001. Internal capabilities, external networks, and performance: A study on technology-based ventures", Strategic Management Journal, 22, 615-640.

Mudambi, R., 2008. Location, Control and Innovation in knowledge intensive industries, Journal of Economic Geography 8, 669-725.

Mudambi, R., Navarra, P., 2004. Is knowledge power? Knowledge flows, subsidiary power and rentseeking within MNCs, Journal of International Business Studies 35, 385-406.

Nohria, N. Gulati, R., 1996, Is slack good or bad for Innovation?, Academy of Management Journal, 39 (5), 1245-1264.

Young, S., Hood.N., Dunlop, S., 1988. Global Strategies, Multinational Subsidiary Roles and Economic Impact in Scotland, Regional Studies, 22 (6), 487-497. 